\title{
FOOD SAFETY: COUNTERING THE MENACE OF FOOD ADULTERATION
}

\section{Sujatha Thankeswaran Parvathy, Sudhir Kumar, Rishikesh kumar and Vijaipal Bhadana}

ICAR-Indian Institute of Agricultural Biotechnology, Ranchi, Jharkhand, India 834010.

You are what you eat is more than a proverb and highly relevant in today's commercialised world. With an alarming increase in population growth and shrinking natural resources such as land and water, the challenges encountered for ensuring food security are enormous. With a total food grain production of 291.95 million tonnes, we are at present self-sufficient to feed our burgeoning population. The challenges are immense, though the agricultural sector has moved from subsistence farming to industrial or commercial agriculture. Food security is not only about the self-sufficiency in food grain production, but on the overall improvement in production and quality of food grain, horticultural as well as animal/poultry products.

From the production to processing to transit to reach the consumers, the final food product passes through several levels and several hands. Safety of food is important throughout the transit, till food is consumed. One of the grave issues in food industry is the adulteration of food. Serious or critical health issues ensue when the adulterated food is consumed. Food adulteration is a serious concern globally.

Food is said to be adulterated when there is a hazardous, toxic component or material in the food, the consumption of which causes serious health issues or is life-threatening. Food adulterations may be incidental or intentional. Improper handling, harvesting or storage may lead to incidental adulteration with extraneous material, fungi, or dead or live insects. Post-harvest losses in India is about Rs 92,651 crore annually (in 2016), due to improper storage and transportation facilities in the agricultural distribution chain. These also contribute to the deterioration of food due to contamination with fungi, fungal toxins, damage by insects, pests etc. Microbial contamination in food causes spoilage of food as well as diseases due to microbial pathogens. Harmful microorganisms, microbial toxins or environmental contaminants in food may cause diseases such as cholera, typhoid, campylobacteriosis, E. coli gastroenteritis, salmonellosis, shigellosis, amoebiasis etc when contaminated food is consumed Vomiting, nausea, fever, abdominal pain, diarrhoea are the common symptoms of food poisoning. Aspergillosis due to Aspergillus in ground nut, botulism due to botulin toxin of Clostridium botulinum in processed or canned foods under anaerobic conditions, Salmonella in poultry, vegetables, eggs, and soybean products, E.coli in salad vegetables, Staphylococcus aureus in meat, Listeria monocytogenes in dairy products, Entameoba histolytica in water etc are few examples of microbial pathogens in food.

Food is intentionally adulterated with harmful chemicals to enhance 
appearance, colour, taste, volume, or weight. The unethical practice of adulteration is done by vendors for the sake of profit or small or marginal gains in monetary or economic aspects that costs heavily on human health. Adulteration is more of a legal term and intentional food adulteration is an offence which is addressed legally. Almost all food manufactured in industrial scale or obtained from outside source is adulterated. Adulteration of food grains, oil, milk, fish, fruits, vegetables, manufactured food, drinks etc are very rampant and common.

Adulterated food is linked to various diseases including life-threatening diseases such as Cancer. The common adulterations in food items are enlisted in Table 1.

Table 1. Food adulteration and health issues

\begin{tabular}{|c|c|c|c|}
\hline & Food item & Adulteration & Health issues \\
\hline 1 & $\begin{array}{l}\text { Food grains, } \\
\text { pulses etc }\end{array}$ & Stones, pebbles, sand, clay etc & $\begin{array}{l}\text { Stomach discomfort, } \\
\text { injury to teeth, stomach, } \\
\text { tongue etc }\end{array}$ \\
\hline 2. & Milk & $\begin{array}{l}\text { Water, Chalk powder, Earthworm, } \\
\text { soap powder hydrogen peroxide, } \\
\text { urea }\end{array}$ & $\begin{array}{l}\text { Vomiting, stomach, heart } \\
\text { issues Cancer etc }\end{array}$ \\
\hline 3 & Butter & Starch powder, mashed potatoes etc & \\
\hline 4 & Ghee & $\begin{array}{l}\text { Vegetable oil, Animal fat, } \\
\text { Vanaspati, mashed potatoes }\end{array}$ & $\begin{array}{l}\text { Anaemia, } \\
\text { enlargement }\end{array}$ \\
\hline 5 & Edible oil & $\begin{array}{l}\text { Mineral oil, argemone seeds, } \\
\text { Karanja oil, Castor Oil, artificial } \\
\text { colours }\end{array}$ & $\begin{array}{l}\text { Glaucoma, Gall bladder } \\
\text { cancer, increased LDL } \\
\text { cholesterol, Paralysis, } \\
\text { Hear issues }\end{array}$ \\
\hline 6 & Fruits & $\begin{array}{l}\text { Wax coating, mixing with rotten } \\
\text { fruits, pesticides, dyes like malachite } \\
\text { green, copper sulphite, ripening } \\
\text { agent like calcium carbide. }\end{array}$ & Stomach disorder, Cancer \\
\hline 7 & Vegetables & Pesticides & Stomach disorder, Cancer \\
\hline 8 & Cinnamon & Cassia bark & $\begin{array}{l}\text { Liver damage, mouth } \\
\text { sores, Cancer }\end{array}$ \\
\hline 9 & Black pepper & Papaya seeds, Black berry & $\begin{array}{l}\text { Allergy of stomach and } \\
\text { skin }\end{array}$ \\
\hline 10 & Mustard seeds & Argemone seeds & Abdominal issues \\
\hline 11 & Cumin seeds & Coloured grass seeds, saw dust & Stomach disorders \\
\hline 12 & Chilli powder & $\begin{array}{l}\text { Red brick powder, Saw dust, } \\
\text { artificial colour Rhodamine B dye, } \\
\text { Red lead salt etc }\end{array}$ & Stomach disorders, Cancer \\
\hline 13 & Turmeric powder & $\begin{array}{l}\text { Yellow aniline dye, Metanil Yellow, } \\
\text { saw dust }\end{array}$ & Stomach disorders, Cancer \\
\hline 14 & $\begin{array}{l}\text { Coriander } \\
\text { Powder }\end{array}$ & Dung powder, Synthetic colours & Stomach disorder, Cancer \\
\hline 15 & Coffee powder & Chicory, Tamarind seeds & Diarrhoea \\
\hline 16 & Tea & Artificial colour & Liver disorder \\
\hline 17 & Sugar & Washing soda, urea, Chalk powder & Stomach and kidney issues \\
\hline 18 & Jaggery & Washing soda, chalk powder & Stomach disorder \\
\hline 19 & Honey & Sugar syrup, antibiotics, colourings & \\
\hline
\end{tabular}




\begin{tabular}{|l|l|l|l|}
\hline & & $\begin{array}{l}\text { and hydroxymethyl furfural } \\
\text { (HMF). }\end{array}$ & \\
\hline 20 & Jam, Juice etc & No-permitted artificial colours & Cancer \\
\hline 21 & Ice cream & $\begin{array}{l}\text { Ethyl acetate, Butyraldehyde, } \\
\text { Nitrate, Washing powder, Gum from } \\
\text { animal parts }\end{array}$ & $\begin{array}{l}\text { Lungs, Kidney and heart } \\
\text { issues }\end{array}$ \\
\hline 22 & Fish & Formalin, Ammonia & $\begin{array}{l}\text { Abdominal pain, vomiting, } \\
\text { coma, renal injury and } \\
\text { death. }\end{array}$ \\
\hline 23 & Meat & $\begin{array}{l}\text { With meat of other animals eg pork } \\
\text { in lamb meat }\end{array}$ & Stomach disorders \\
\hline
\end{tabular}

Food adulteration has become sophisticated and hence detection of adulteration for deterrence is a complex, but essential measure required to ensure safety of the food products that are consumed.

Prevention of Food Adulteration Act,1954 and subsequent amendments in 2000, 2002, Fruit Products Order, 1955, Meat Food Products Order,1973, Vegetable Oil Products (Control) Order, 1947, Milk and Milk Products Order, 1992 etc were consolidated into Food Safety and Standard Act, 2006, to prevent food adulteration to ensure quality standards of food and its safety for human consumption. Food Safety and Standards Authority of India (FSSAI) and the State Food Safety Authorities under the Ministry of Health and Family Welfare are responsible for enforcing various provisions of the Act. Central Food Laboratory is responsible to test and analyse food items. Penalties are imposed for violations of the act which also prevents import of adulterated or misbranded food.

\section{Detection of food adulteration}

Detect Adulteration with Rapid Test (DART) booklet of FSSAI is a compilation of quick tests that can be easily carried out at households to detect food adulterants. Milk adulterated with water when placed on a slanting surface, does not leave a mark, while pure milk leaves a white trail. Milk with detergent lathers well when 5-10 ml of milk mixed with equal volume of water is agitated. Milk with starch turns blue when 2-3 drops of tincture iodine is added to adulterated milk. This can be used to test for presence of starch in foods such as ghee/butter with mashed potatoes, starch powder etc. Edible saturated fat like coconut oil solidifies upon refrigeration at 4 degrees for 30 minutes, while other oils float on top if the coconut oil is adulterated. Wheat adulterated with bran shows floating of bran on top of water when wheat is taken in a glass of water. Adulteration in food grains and pulses can be detected by close examination such as black dhatura seeds in dal. One of the worst type of adulteration in dal is that of kesari dal which is neurotoxic and causes paralysis. Kesari dal is square in appearance and slanting from one side when taken in a flat glass plate. Sella rice adulterated with turmeric turns red when soaked lime is added. Colour in grains or pulses can be detected by adding grains in water and verifying for coloured water or by rolling a piece of cotton with water or oil on top of the grains and checking for the colour in cotton. Rhodamine dye 
in ragi is detected using wet cotton. Artificial colour in fruits and vegetables can also be detected using wet cotton, dipping in water and looking for colour of water and also by spread on colour in a wet blotting sheet. Papaya seeds in black pepper float on water while pepper seeds remain on bottom. Mustard seeds are smooth and yellow inside, while adulterant argemone seeds have rough surface and are white inside. Artificial colour in chilli powder descends as colour streaks when adulterated chilli powder is put in a glass of water. But saw dust in chilli powder floats on surface. Artificial colour in turmeric is seen as bright yellow colour in water when turmeric is added to water. Adulteration of honey with sugar can be identified by adding a drop of honey in water. Pure honey will not disperse but the one with sugar does. Also cotton drenched in pure honey burns, but the adulterated one burns with cracking sound, due to the presence of water. Adulterants in jaggery such as chalk powder settles as residue after dissolving $10 \mathrm{~g}$ of jaggery in a glass of water. Chicory in coffee powder sinks when added to water while coffee powder floats. Iron filing in tea can be detected using magnet. Formalin, a carcinogen is used for preservation of fish. A kit developed by FSSAI and ICARCentral Institute of Fisheries Technology (CIFT), Kochi, can be used to detect formalin contamination in fish. A paper provided in the kit is rubbed against skin of fish and a reagent is added. Formalin contamination is confirmed if in the paper turns blue and yellow indicates no contamination.

In addition to these simple tests, several biochemical, biotechnological and sophisticated analytical techniques and instruments could be used for analysing food quality and detecting adulterants in food.

Biotechnological methods can be used for detection of adulteration in food. Recombinase polymerase amplification (RPA) is commonly used for detection of salmonella in food and for detection of meat adulteration with meat of other animals, which are cheap. RPA uses species-specific primers for amplification at room temperature $37-42{ }^{\circ} \mathrm{C}$ using recombinase which can bind primers to double stranded DNA. SSB or single stranded binding protein binds to displaced single strands of DNA to prevent them from being displaced and a strand displacing polymerase synthesises DNA using the two-opposing primers bound to the target DNA. Exponential and specific amplification of DNA occurs at optimal temperatures (37$42{ }^{\circ} \mathrm{C}$ ), in 3-10 minutes in an isothermal amplification process which obviates the need of a thermal cycler. RPA is a rapid and specific detection process. DNA based methods such as molecular markers (RAPD and SCAR) were used for biological adulterant detection in powdered black pepper, chilli and turmeric and can be employed for authentication of a wide range of food and agricultural commodities. Authenticity of rice varieties can be checked using DNA based methods such as molecular markers and protein-based methods, since unscrupulous traders mix low-grade, low-cost grain products with high quality export varieties such as Basmati. 
Sophisticated methods of detection include chromatography such as liquid chromatography, Gas chromatography (GC) high-performance thin-layer chromatography (HPTLC), nuclear magnetic resonance (NMR), differential calorimetry, mass spectrometry (MS), Fourier transform infrared attenuated total reflectance spectroscopy (FT-IR ATR), vibrational spectroscopies such as near-infrared, mid-infrared, Raman; NMR spectroscopy, etc

\section{Food Safety Certification}

Certain schemes are recognised by the Global Food Safety Initiative (GFSI), such as FSSC (Food Safety Standards Certification) 22000, BRC Food, IFS (International Featured Standard), BRC Storage \& Distribution, BRC Packaging and Packaging Manufacturing, ISO 22000, Dutch HACCP (Hazard Analysis and Critical Control/Points) and BRC Agents \& Brokers. Other international food safety standards include AHA (Allergie, Haut, Asthma) - Allergy management, Codex Verified Approval Scheme, Hygiene Monitored Approval Scheme, IFS Broker, ISO 22000 - Food Safety Management, ISO 28000 - Supply Chain Security Management, ISTA (International Seed Testing Association), Marine Stewardship Council, Non-GMO certification, Organic Certification etc . Certification of an organization as per the ISO 22000 / HACCP / or any other food safety standard assures the implementation of food safety management system, food safety policy and the requirements of ISO 22000.AGMARK, BIS (Bureau of Indian Standards), ISO, HACCP, India GHP (Good Hygienic Practice) are the 5 types of food certifications in India.
Customers should be alert and exercise caution and look for the standard marks or labels such as ISI mark, AGMARK, FSSAI standard mark, date of packing and date of expiry etc in the food products while purchasing. The government also should ensure legal measures or punishments for food adulteration and hike the penalty for food adulteration. Right to food is important and right to safe food is critical.

\section{REFERENCES}

Alum, E.A., Urom, S.M.O.C, Ben, C.M.A (2016). Microbiological Contamination Of Food: The Mechanisms, Impacts And Prevention. International Journal of Scientific and Technology Research, 5(3): 65-78.

Caoa,Y., Zheng, K., Jiang, J., Wub, J., Shia, F., Song, $X$ and Jiang, Y. (2018) A novel method to detect meat adulteration by recombinase polymerase amplification and SYBR green I. Food Chemistry, 266:73-78.

Kizhakayil, D and Bhas, S (2010) Molecular Marker Based Adulteration Detection in Traded Food and Agricultural Commodities of Plant Origin with Special Reference to Spices. Current Trends in Biotechnology and Pharmacy, 4(1):454-489

Kumari, K., Devegowda, S.R., Pavan M K., Kushwaha,S (2019) Post Harvest Losses in India. Agrobios Newsletter, 17(11): 136137.

\section{Vemireddy LR, Satyavathi VV, Siddiq EA,} Nagaraju J. (2015) Review of methods for the detection and quantification of adulteration of rice: Basmati as a case study. J Food Sci Technol. 52(6):31873202. doi:10.1007/s13197-014-1579-0 
https://www.fssai.gov.in/book-

details.php? bkid=201 https://www.fssai.gov.in/upload/media/5 b4da84e6d51eFSSAI News Adulterated Honey_timesNow_16_06_2018.pdf

1878035b34b558a3b48DART\%20Book.pdf 